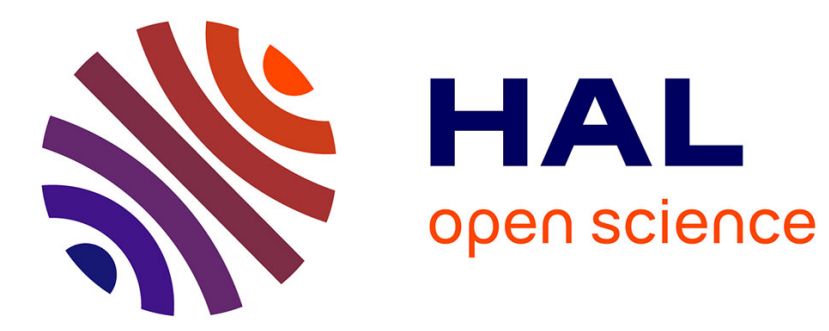

\title{
Soil organic carbon sequestration in relation to revegetation on the Loess Plateau, China
}

Man Cheng, Zhijing Xue, Yun Xiang, Frédéric Darboux, Shaoshan An

\section{To cite this version:}

Man Cheng, Zhijing Xue, Yun Xiang, Frédéric Darboux, Shaoshan An. Soil organic carbon sequestration in relation to revegetation on the Loess Plateau, China. Plant and Soil, 2015, 397 (1), pp.31-42. $10.1007 / \mathrm{s} 11104-015-2486-5$. hal-01275655

\section{HAL Id: hal-01275655 \\ https://hal.science/hal-01275655}

Submitted on 17 Feb 2016

HAL is a multi-disciplinary open access archive for the deposit and dissemination of scientific research documents, whether they are published or not. The documents may come from teaching and research institutions in France or abroad, or from public or private research centers.
L'archive ouverte pluridisciplinaire HAL, est destinée au dépôt et à la diffusion de documents scientifiques de niveau recherche, publiés ou non, émanant des établissements d'enseignement et de recherche français ou étrangers, des laboratoires publics ou privés.

$$
\text { Copyright }
$$




\section{Title Page}

\section{Soil organic carbon sequestration in relation to revegetation on the}

\section{Loess Plateau, China}

\section{Man Cheng • Zhijing Xue • Yun Xiang • Frédéric Darboux · Shaoshan An}

Concise and informative title: Revegetation and carbon sequestration

Man Cheng (chengman1988@126.com)

State Key Laboratory of Soil Erosion and Dryland Farming on the Loess Plateau, Northwest A\&F University, Yang ling, Shaanxi 712100, China

Zhijing Xue (2032065@163.com)

State Key Laboratory of Soil Erosion and Dryland Farming on the Loess Plateau, Northwest A\&F University, Yang ling, Shaanxi 712100, China

Yun Xiang (xy020824@163.com)

State Key Laboratory of Soil Erosion and Dryland Farming on the Loess Plateau, Northwest A\&F University, Yang ling, Shaanxi 712100, China

\section{Frédéric Darboux (Frederic.Darboux@orleans.inra.fr)}

INRA, UR0272, UR Science du sol, Centre de Recherche Val de Loire, CS 40001 - Ardon, F-45075 Orléans

Cedex 2, France

Corresponding author: Shaoshan An

E-mail: shan@ms.iswc.ac.cn

Institution: Institute of Soil and Water Conservation

Invoice address: 26 Xinong Rd., Yangling. Shaanxi, China

Full telephone: $86-29-87012871$

Fax No.: 86-29-87012210 


\title{
Soil organic carbon sequestration in relation to revegetation on the Loess Plateau, China
}

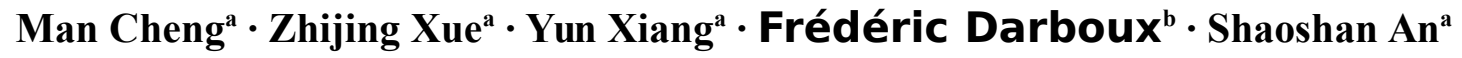 \\ astate Key Laboratory of Soil Erosion and Dryland Farming on the Loess Plateau, Northwest A\&F University, Yang ling, \\ Shaanxi 712100, China \\ bINRA, UR0272, UR Science du sol, Centre de Recherche Val de Loire, CS 40001 - Ardon, F-45075 Orléans Cedex 2, \\ France
}

\begin{abstract}
Background and Aims Estimating the distribution of soil organic carbon (SOC) is essential for improving SOC sequestration. Our objectives were (1) to quantify the dependency of SOC stocks on vegetation type; (2) to identify in which aggregate sizes and chemical forms the SOC was stored; and (3) to determine which vegetation type was the most effective at sequestering SOC.

Methods The studied vegetation types were shrubland CK16 (16-year-old Caragana korshinskii Kom.), shrubland CK26 (26-year-old C. korshinskii Kom.), shrubland AS (Armeniaca sibirica Lam.), natural grassland and artificial pasture. We investigated SOC stocks and measured soil carbon, in $<0.25 \mathrm{~mm}, 0.25-1 \mathrm{~mm}, 1-2 \mathrm{~mm}$, 2-5 $\mathrm{mm}$ and 5-8 $\mathrm{mm}$ sized aggregates, and carbon fractions [humus (HS-C), humic acid (HA-C), fulvic acid (FAC)] from CK shrublands, natural grassland and cropland.

Results The SOC stocks were the greatest for CK shrublands and natural grassland. Compared with cropland, shrubland $\mathrm{CK}$ caused increases in $>2 \mathrm{~mm}$ sized aggregate $\mathrm{C}$ stocks. The 1-2, 2-5, 5-8 mm size aggregate $\mathrm{C}$ stocks were the highest in the natural grassland. HS-C was 1.4, 3.1, and 4.1 $\mathrm{Mg} \mathrm{ha}^{-1}$ greater in shrubland CK16, shrubland CK26, and natural grassland, respectively, than in cropland.

Conclusions Conversion to C. korshinskii shrublands and protection of natural grassland should be promoted to improve the contribution of vegetation to SOC sequestration.
\end{abstract}

Keywords: revegetation $\cdot$ soil organic carbon $\cdot$ stocks $\cdot$ aggregate $\cdot$ shrubland $\cdot$ grassland 
Version définitive du manuscrit publié dans / Final version of the manuscript published in :

Plant and Soil, 2015, 397(1), 31-42 http://dx.doi.org/10.1007/s11104-015-2486-5

\section{Introduction}

Soils play an important role in the global carbon cycle. Soil organic carbon (SOC) storage is estimated at approximately $1500 \mathrm{Pg}$ globally, about two and three times the size of carbon pools in the atmosphere and vegetation, respectively (Jobbágy and Jackson 2000; Lal 2004). The SOC stock is an important part of the atmospheric carbon sink (Schimel et al. 2001). In addition, soil organic matter has long been understood to be a critical constituent of the physical, chemical, and biological quality of soil (Grigal, 2000), while cultivation typically tends to reduce the carbon content in soils (Qiu et al. 2012). Hence, increasing soil carbon content is essential to enhance soil quality, to sustain and improve food production, to maintain clean water, and to reduce atmospheric $\mathrm{CO}_{2}$ (Lal 2004).

The extent of carbon retention in soils depends, among other things, on the nature of soil aggregation (Carter, 1996). Soil aggregates are important components of soil structure, and influence carbon accumulation by providing physical protection for SOC (Six et al. 2000, 2004). The physical protection provided by aggregates determines the stability of new C input into soils, and thus the balance of C (Beare et al. 1994; Kristiansen et al. 2006; Razafimbelo et al. 2008). It is often considered that there is a short-term storage of SOC in macroaggregates $(>0.25 \mathrm{~mm}$ diameter) and long-term storage in microaggregates $(<0.25 \mathrm{~mm}$ diameter) (Six et al. 2002). Previous studies showed that macroaggregate carbon stocks are sensitive to land-use and management (Ashagrie et al. 2005, 2007; Li and Pang 2010; Steffens et al. 2009).

Soil organic matter is a heterogeneous pool, and includes a low-molecular-weight fraction (non-humic compounds) and a high-molecular-weight fraction (humic substances) (Prentice and Webb 2010). The organic carbon in humic substances realistically reflects carbon sequestration in the soils (Leng et al. 2009). Humic substances (HS) can be chemically separated into fulvic and humic acids based on their solubility. Humic acids (HA) are more polymerized and aromatized than fulvic acids (FA). These changes of carbon accumulation in chemically-separated carbon fractions can provide insights into the mechanisms of carbon sequestration.

Revegetation, i.e., the conversion of cropland into perennial vegetated land, offers opportunities to sequester soil organic carbon (Chang et al. 2011). Revegetation may lead to accumulation of SOC by increasing carbon derived from the new vegetation type and decreasing carbon loss by decomposition and erosion (Laganière et al., 2010). Numerous studies have been conducted investigating the effects of revegetation on soil carbon sequestration (Mensan et al. 2003; Ashagrie et al. 2005; Yue et al. 2007; Han et al. 2008; Haile et al. 2008; An et al. 2010; Jia et al. 2010; Lenka et al. 2012; Wei et al. 2012; Feng et al. 2013). However, the accumulation of soil carbon fractions induced by revegetation is not well understood. Understanding the responses of aggregate-associated carbon and chemically-separated carbon fractions to revegetation is therefore fundamental to the assessment of the effect of revegetation on soil organic carbon sequestration and to the prediction of carbon dynamics in soils.

In the last century, increasing population pressure in China resulted in ecological degradation. To prevent further deterioration of natural ecosystems, the Chinese government launched a series of nationwide conservation projects in the 1980s. These projects, such as the "Grain for Green" Project, focus on the rehabilitation of damaged ecosystems. A pilot program of the "Grain for Green" Project was conducted in our study area. In this pilot program, croplands were converted into Caragana korshinskii Kom. shrublands in 1984 and 1994. The other vegetation types in the area were Armeniaca sibirica Lam. shrubland, natural grassland, and artificial pasture. In this paper, we investigated SOC stocks by measuring soil carbon in $<0.25 \mathrm{~mm}, 0.25-1 \mathrm{~mm}$, 1-2 $\mathrm{mm}, 2-5 \mathrm{~mm}$ and 5-8 $\mathrm{mm}$ sized aggregates and chemically-separated carbon fractions, i.e., humus (HS), humic acid (HA), and fulvic acid (FA). We considered five types of vegetation: shrubland CK16, shrubland CK26, shrubland AS, natural grassland, artificial pasture, plus cropland used as the reference. The main objectives were (1) to quantify SOC stocks among the types of vegetation; (2) to identify in which aggregate size 
Version définitive du manuscrit publié dans / Final version of the manuscript published in :

Plant and Soil, 2015, 397(1), 31-42 http://dx.doi.org/10.1007/s11104-015-2486-5

and under which chemical form the SOC was stored; and (3) to determine which vegetation type was the most effective at sequestering SOC.

\section{Materials and methods}

Study area and vegetation types

The study was conducted at Guyuan Ecological Research Station of the Institute of Soil and Water Conservation, Chinese Academy of Sciences. This Station is located in the Shanghuang study area $\left(8 \mathrm{~km}^{2}\right)$, near the city of Guyuan (Ningxia autonomous region), between $106^{\circ} 26^{\prime} \mathrm{E}$ and $106^{\circ} 30^{\prime} \mathrm{E}$ and between $35^{\circ} 59^{\prime} \mathrm{N}$ and $36^{\circ} 02^{\prime} \mathrm{N}$ (Fig. 1). The Shanghuang study area is in the "hilly-gully" region of the western Loess Plateau, with an altitude ranging from 1534 to $1822 \mathrm{~m}$ above sea level. The study area has a sub-arid climate that is characterized by heavy seasonal rainfalls with recurrent local flooding and drought. The mean annual temperature is $7{ }^{\circ} \mathrm{C}$. The average annual rainfall is $400 \mathrm{~mm}$. The studied pedons were classified as Entisols, according to Soil Taxonomy (Soil Survey Staff, 2010).

The typical natural vegetation of this region is grassland (Stipa bungeana Trin.). The inhabitants used cropland for subsistence (mostly wheat, with very low fertilizer input) and natural grassland to feed cattle. In the 1980s, the pilot program "National ecological environment construction and comprehensive agricultural experimental demonstration project" was established to promote the recovery of damaged ecosystems. Through this program, in 1984 and in 1994, part of the cropland was successively converted into C. korshinskii shrubland. Additionally, grazing was prohibited on natural grassland. The artificial pasture (Medicago sativa L.) is mowed several times a year to feed cattle. Hence, the study area is currently composed of shrubland, grassland and cropland. The vegetation was classified into six types (Fig. 1 and Table 1): shrubland CK16 (16-year-old $C$ Korshinskii), shrubland CK26 (26-year-old C Korshinskii), shrubland AS (Armeniaca sibirica Lam.), natural grassland (Stipa bungeana Trin.), artificial pasture (Medicago sativa L.) and cropland (considered as a reference).

\section{Soil sampling and analysis}

For SOC stocks, soil samples were taken from all six vegetation types. A global positioning system (GPS) was used to locate the sampling sites. In 2010, a total of 99 sites were selected (Fig. 1c): 17 for shrubland CK16, 17 for shrubland CK26, 12 for shrubland AS, 15 for natural grassland, 19 for artificial pasture, and 19 for cropland. The number of sites was proportional to the surface areas of each vegetation type. However, because of limitations imposed by the varied topography, there were not enough field sites available for conducting all of the sampling as planned. At each site, three replicated plots $(30 \mathrm{~m} \times 30 \mathrm{~m})$ were randomly established. For each plot, samples were taken at two depths $(0-20 \mathrm{~cm}$ and 20-40 cm). For each depth, five core samples were taken using a $20 \mathrm{~cm} \times 5 \mathrm{~cm}$ soil auger and mixed to form a composite sample of approximately $1 \mathrm{~kg}$. Soil bulk density was also measured at each plot for the $0-20 \mathrm{~cm}$ and $20-40 \mathrm{~cm}$ depths using a $5.0 \mathrm{~cm}$ long by $5.0 \mathrm{~cm}$ diameter stainless steel cutting ring. These soil cores were dried at $105{ }^{\circ} \mathrm{C}$ for $24 \mathrm{~h}$. Additionally, to measure the plant surface coverage and above-ground biomass, three $1 \mathrm{~m} \times 1 \mathrm{~m}$ subplots were established in each plot for natural grassland and artificial pasture, and $5 \mathrm{~m} \times 5 \mathrm{~m}$ subplots were established in shrublands. The details of the vegetation characteristics are shown in Table 1.

Considering that shrubland CK16, shrubland CK26, and natural grassland represented the main environmental protection measures in the study area (Fig. 1d), we selected one site per vegetation type to collect undisturbed soil samples to study aggregate size distribution, aggregate carbon content and carbon chemistry. Cropland was also sampled to be used as a reference. The physiographic conditions and slope gradients of these sites are shown in Table 2. At each site, three replicated plots were established $(30 \mathrm{~m} \times 30 \mathrm{~m}$ for the two shrublands, and $10 \mathrm{~m} \times 10 \mathrm{~m}$ for natural grassland and cropland). On the cropland, the samples were collected one month after wheat harvest. From each plot, three undisturbed soil samples were collected in aluminum 
Version définitive du manuscrit publié dans / Final version of the manuscript published in :

Plant and Soil, 2015, 397(1), 31-42 $\quad$ http://dx.doi.org/10.1007/s11104-015-2486-5

containers at depths of 0-20 cm and 20-40 cm. A total of 72 undisturbed soil samples were obtained, (18 soil samples per vegetation type). The samples were air dried at room temperature. Each sample was passed through an $8 \mathrm{~mm}$ sieve to remove large roots, stones, and macrofauna.

The aggregate separation was performed using a modified Yoder method (Zhu, 1982), with a set of sieves with openings of $0.25,0.5,1,2$, and $5 \mathrm{~mm}$. The sieve set was rapidly immersed in distilled water and oscillated with a displacement of approximately $4 \mathrm{~cm}$ at 37 cycles per minute for 3 minutes. All fractions were dried at $70^{\circ} \mathrm{C}$ overnight and then weighed. All samples were ground to pass through a $0.25 \mathrm{~mm}$ sieve before measuring SOC. SOC concentrations of the bulk soil samples and the aggregate fractions were determined using potassium dichromate $\left(\mathrm{K}_{2} \mathrm{Cr}_{2} \mathrm{O}_{7}\right)$ titration (Walkley and Black, 1934; Bao 2005), which involves oxidizing an aliquot of soil $(0.5 \mathrm{~g})$ with a solution of $\mathrm{K}_{2} \mathrm{Cr}_{2} \mathrm{O}_{7}$ and $\mathrm{H}_{2} \mathrm{SO}_{4}$ at $170{ }^{\circ} \mathrm{C}$. The excess dichromate is titrated with $0.25 \mathrm{~mol} \mathrm{~L}^{-1}$ $\mathrm{FeSO}_{4}$. An oxidation factor of 1.1 is used, based on the supposition that $91 \%$ of OC is oxidized in the procedure.

Chemically-separated carbon fractions of soil, i.e., humus (HS), humic acid (HA), and fulvic acid (FA), were determined by an extraction method of $\mathrm{NaOH}$ and $\mathrm{Na}_{4} \mathrm{P}_{2} \mathrm{O}_{7}$ mixed solution (Yan 1988). Humic acids were extracted from each soil sample using a solution of $0.1 \mathrm{M} \mathrm{NaOH}$ and $0.1 \mathrm{M} \mathrm{Na}_{4} \mathrm{P}_{2} \mathrm{O}_{7}$ at $70{ }^{\circ} \mathrm{C}$ for 60 min. The dark brown alkaline supernatant solution, corresponding to the total alkali-extractable HS, was separated into the acid-insoluble $\mathrm{HA}$ and the acid-soluble FA fractions by acidifying the alkaline supernatant to $\mathrm{pH} 1.0$ with $0.5 \mathrm{M}$ $\mathrm{H}_{2} \mathrm{SO}_{4}$. The HA was washed successively with $0.025 \mathrm{M} \mathrm{H}_{2} \mathrm{SO}_{4}$ and water, and then dissolved in $0.05 \mathrm{M} \mathrm{NaOH}$. The carbon concentrations of HS (HS-C) and HA (HA-C) were determined through potassium dichromate titration, and the carbon (C) concentration of FA (FA-C) was calculated by subtracting the HA-C from the HS-C.

SOC stocks (SOC stocks $\mathrm{ESM}_{\mathrm{E}}, \mathrm{Mg} \mathrm{ha}^{-1}$ ) were calculated using a modified equivalent soil mass (ESM) method (Bambrick et al., 2010) based on the approach of Ellert and Bettany (1995). A hypothetical bulk density $\left(\mathrm{BD}_{\mathrm{b}}\right)$ of $1.00 \mathrm{Mg} \mathrm{m}^{-3}$ was multiplied by the soil thickness for each sampling depth $(0-20$ and $20-40 \mathrm{~cm})$, and by the surface area per hectare $\left(10^{4} \mathrm{~m}^{2} \mathrm{ha}^{-1}\right)$, to produce an equivalent soil mass for each layer $\left(\mathrm{M}_{\text {equiv }}, \mathrm{Mg} \mathrm{ha}^{-1}\right)$.

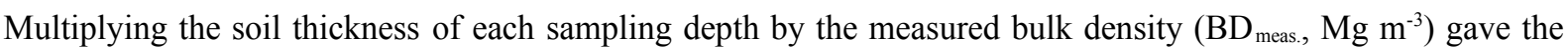
actual soil mass of each layer $\left(\mathrm{M}_{\text {meas. }}, \mathrm{Mg} \mathrm{ha}^{-1}\right)$.

$\mathrm{M}_{\text {equiv. }}=\mathrm{BD}_{\mathrm{b}} \times \mathrm{T} \times 10^{4} \mathrm{~m}^{2} \mathrm{ha}^{-1}$

$\mathrm{M}_{\text {meas. }}=\mathrm{BD}_{\text {meas. }} \times \mathrm{T} \times 10^{4} \mathrm{~m}^{2} \mathrm{ha}^{-1}$

where $\mathrm{T}$ is the thickness $(\mathrm{m})$ of the soil layer.

The adjusted soil thickness $\left(\mathrm{T}_{\mathrm{c}}, \mathrm{m}\right)$ required to reach the equivalent soil mass was calculated as:

$\mathrm{T}_{\mathrm{c}}=\mathrm{T}+\left[\left(\mathrm{M}_{\text {equiv. }}-\mathrm{M}_{\text {meas. }}\right) \times 10^{-4}\right.$ ha $\left.\mathrm{m}^{-2}\right] \div \mathrm{BD}_{\text {meas. }}$

The ESM SOC stocks $\left(\mathrm{Mg} \mathrm{ha}^{-1}\right)$ of each soil layer was calculated as:

SOC stocks $\mathrm{ESM}=[\mathrm{C}] \times \mathrm{BD}_{\text {meas. }} \times \mathrm{T}_{\mathrm{c}} \times 10^{4} \mathrm{~m}^{2} \mathrm{ha}^{-1} \times 10^{-3} \mathrm{Mg} \mathrm{kg}^{-1}$

where $[\mathrm{C}]$ is the elemental concentration $\left(\mathrm{kg} \mathrm{Mg}^{-1}\right)$ of soil C.

Aggregate carbon stocks and the carbon stocks $\left(\mathrm{Mg} \mathrm{ha}^{-1}\right)$ in HS-C, FA-C and HA-C were calculated for shrubland CK16 and CK26, natural grassland and cropland. Aggregate amount, aggregate C stocks, and C fraction stocks were calculated as follows:

Aggregate amount $\left(\mathrm{Mg} \mathrm{ha}^{-1}\right)=\mathrm{T}_{\mathrm{c}} \times \mathrm{BD}_{\text {meas. }} \times \mathrm{M}_{i} \times 10^{4} \mathrm{~m}^{2} \mathrm{ha}^{-1}$

Aggregate $\mathrm{C}$ stocks $\left(\mathrm{Mg} \mathrm{ha}^{-1}\right)=$ Aggregate amount $\times\left[\right.$ Aggregate $\left.\mathrm{SOC}_{i}\right] \times 10^{-3} \mathrm{Mg} \mathrm{kg}^{-1}$

$\mathrm{C}$ fraction stocks $\mathrm{ESM}=[\mathrm{C}$ fraction $] \times \mathrm{BD}_{\text {meas. }} \times \mathrm{T}_{\mathrm{c}} \times 10^{4} \mathrm{~m}^{2} \mathrm{ha}^{-1} \times 10^{-3} \mathrm{Mg} \mathrm{kg}^{-1}$

where $\mathrm{M}_{i}$ is the percentage of the $i$ th aggregate size fraction (\%), [Aggregate $\mathrm{SOC}_{i}$ ] is the concentration in SOC of the $i$ th aggregate size fraction ( $\mathrm{kg} \mathrm{Mg}^{-1}$ aggregate), and [C fraction] is the concentration of soil carbon fraction $\left(\mathrm{kg} \mathrm{Mg}^{-1}\right)$.

Statistical analysis 
Version définitive du manuscrit publié dans / Final version of the manuscript published in : Plant and Soil, 2015, 397(1), 31-42 http://dx.doi.org/10.1007/s11104-015-2486-5

SPSS 11.0 statistical software was used for the statistical analysis. Revegetation type and soil depth were considered as the main effects, and replications were treated as random effects. Analyses of variance were performed using the ANOVA procedure in SPSS. The Bonferroni method $(P<0.05)$ was used to assess the differences in SOC stocks, soil chemically-separated carbon fraction stocks, aggregate amount, aggregate carbon concentration and aggregate $\mathrm{C}$ stocks. Power analysis was conducted using the PROC MIXED procedure of SAS (SAS Institute, 2001). The Power calculations were based on a 0.05 probability of TypeIerror.

\section{Results}

\section{SOC stocks according to vegetation type and depth}

SOC stocks of cropland were $14 \mathrm{Mg} \mathrm{ha}^{-1}$ at 0-20 cm depth and $12 \mathrm{Mg} \mathrm{ha}^{-1}$ at 20-40 cm depth (Table 3). There was no significant difference from the SOC stocks of artificial pasture, shrubland AS, shrubland CK16 and cropland. SOC stocks in natural grassland and shrubland CK26 were significantly greater than in cropland by approximately $18 \mathrm{Mg} \mathrm{ha}^{-1}$ and $11 \mathrm{Mg} \mathrm{ha}^{-1}$ for the 0-20 cm and 20-40 cm depths, respectively. Except for cropland and artificial pasture, SOC stocks were significantly higher at 0-20 cm depth than at 20-40 cm depth. Combining the two layers, SOC stocks at 0-40 cm depth were the largest for shrubland CK26 and natural grassland ( $>50 \mathrm{Mg} \mathrm{ha}^{-1}$ ). SOC stocks were roughly half as much (approximately $25 \mathrm{Mg} \mathrm{ha}^{-1}$ ) for shrubland AS, artificial pasture and cropland, with shrubland CK16 being intermediate.

We used tolerable uncertainty of $25 \%$ above and below the mean of SOC stocks (Kravchenko and Robertson 2011; Thomas 1997). The power values of a statistically significant ( $\alpha=0.05)$ effect in SOC stocks are shown in Fig 2. Our power analysis showed that the power values were $>80 \%$ for SOC stocks of all the vegetation types at 0-20 and 20-40 cm soil layers. These high power values illustrate that 99 sites and three replicated plots in each site could meet the tolerated uncertainty for estimating mean SOC stocks of vegetation types. And based on the results of power analysis, the above results of no significant differences among artificial pasture, shrubland AS, shrubland CK16 and cropland could be accepted in our study.

\section{Soil aggregate $C$ stocks in different revegetation types}

Shrubland CK16, shrubland CK26, and natural grassland had significantly lower amounts of soil aggregates in the $<0.25 \mathrm{~mm}, 0.25-1 \mathrm{~mm}$ and 1-2 mm sizes compared with cropland, and significantly higher amounts of soil aggregates of 5-8 $\mathrm{mm}$ size, at both the 0-20 and 20-40 $\mathrm{cm}$ depths (Fig. 3a). For shrubland CK16, shrubland CK26, natural grassland, and cropland, the amounts of soil aggregates in the $<0.25 \mathrm{~mm}$ size were always lower at $0-20 \mathrm{~cm}$ than at 20-40 cm. Except for CK26 shrubland, the amounts of soil aggregates of 5-8 mm size were greater at $0-20 \mathrm{~cm}$ than at $20-40 \mathrm{~cm}$ depth. Combining the two layers (calculated from Fig. 3a, not shown), the amounts of soil aggregates of $<0.25 \mathrm{~mm}, 0.25-1 \mathrm{~mm}$ and 1-2 mm size were less for shrubland CK16, shrubland CK26 and natural grassland than for cropland; the amount of 2-5 mm sized aggregates was significantly higher for natural grassland than other vegetation types; the amount of 5-8 $\mathrm{mm}$ sized aggregates was the highest for natural grassland (approximately $1740 \mathrm{Mg} \mathrm{ha}^{-1}$ ), and the amount was the lowest for cropland (approximately 640 $\left.\mathrm{Mg} \mathrm{ha}^{-1}\right)$, with shrubland CK16 and CK26 being intermediate.

Apart from soil aggregates of $<0.25 \mathrm{~mm}$ size at $20-40 \mathrm{~cm}$ depth, aggregate-associated carbon concentrations of natural grassland were significantly higher than those of cropland for all the sizes and depths (Fig. 3b). The carbon concentrations of $<0.25$ and $0.25-1 \mathrm{~mm}$ sized aggregates of shrubland CK16 and CK26 were significantly higher than those of cropland at $0-20 \mathrm{~cm}$ depth, whereas they were similar to those of cropland at $20-40 \mathrm{~cm}$ depth. The carbon concentrations of 1-2 mm sized aggregates of shrubland CK26 were significantly higher than those of cropland only at 20-40 cm depth. The carbon concentrations of 2-5 mm sized aggregates of shrubland CK16 and CK26 were the same as those of cropland at both depths. The carbon concentrations of 5-8 mm sized aggregates of shrubland CK16 were 2.5 and $2.6 \mathrm{~g} \mathrm{~kg}^{-1}$ higher than those of cropland at 0-20 and 20-40 cm depth. 
Version définitive du manuscrit publié dans / Final version of the manuscript published in : Plant and Soil, 2015, 397(1), 31-42 http://dx.doi.org/10.1007/s11104-015-2486-5

The carbon concentration of 5-8 mm sized aggregates of shrubland CK26 was higher than that of cropland only at $20-40 \mathrm{~cm}$ depth.

Sites that had been revegetated, i.e., shrubland CK16 and shrubland CK26, had significantly higher carbon stocks in the 5-8 mm size fractions compared with cropland at both depths (Fig. 3c). However, natural grassland had the highest carbon stock in the $5-8 \mathrm{~mm}$ size fraction compared with all other vegetation types at both depths. This was also true for the 1-2 and 2-5 mm sizes. For the $<0.25 \mathrm{~mm}$ size fraction, cropland had the lowest carbon stock at 0-20 cm depth, and the highest carbon stocks at 20-40 cm depth. Considering the 0-40 cm layer, 1-2, 2-5 and 5-8 $\mathrm{mm}$ sized aggregate-associated carbon stocks of natural grassland were the highest (calculated from Fig. $3 \mathrm{c}$, not shown). For the 2-5 and 5-8 mm size fractions, C stocks of shrubland CK16 and CK26 were greater than that of cropland.

The dependency of carbon stocks of chemically-separated fractions on vegetation types

The carbon stocks in HS, HA and FA differed among the vegetation types (Table 4). At 0-20 cm depth, HSC stocks of natural grassland, shrubland CK16, and shrubland CK26 were significantly larger than those of cropland. At 20-40 cm depth, HS-C stocks of natural grassland and shrubland CK26 were larger than those of cropland, but HS-C stocks of shrubland CK16 were not significantly different from those of cropland. FA-C stocks accounted for 60-90 \% of HS-C stocks. FA-C stocks of shrubland CK16, shrubland CK26 and natural grassland were significantly higher than those of cropland at $0-20 \mathrm{~cm}$ depth, and FA-C stocks of natural grassland were significantly greater than those of cropland at $20-40 \mathrm{~cm}$ depth. HA-C stocks of all vegetation types were similar at $0-20 \mathrm{~cm}$ and $20-40 \mathrm{~cm}$ depth. HS-C and FA-C stocks of a given vegetation type differed among the two depth ranges only for shrubland CK16. HA-C stocks were higher at $0-20 \mathrm{~cm}$ depth for all vegetation types, except for shrubland CK26.

\section{Discussion}

The consequences of revegetation on the soil organic carbon stocks

SOC stocks were significantly greater in natural grassland and $C$. korshinskii shrublands than those in cropland. This finding is consistent with previous studies (Mensan et al. 2003; Jia et al. 2010; An et al. 2010; Lenka et al. 2012) that showed that SOC increased with the development of shrubs and grass. The lower SOC stocks in cropland have been attributed to lower carbon inputs and higher carbon mineralization (Skjemstad et al. 2008; Nyamadzawo et al. 2009). Additionally, farmers on the Loess Plateau use conventional tillage, which induces large carbon losses (Nieto et al. 2012). Therefore, natural grassland and C. korshinskii shrubland are recommended to enhance carbon sequestration in soil. Furthermore, we found that SOC stocks increased with the revegetation time in shrubland CK. Jia (2010) suggested that SOC increased with the development of shrubs. We consider the higher SOC stocks in shrubland CK26 to be related to the increase in above-ground biomass (Table 1) and root-system biomass with time after planting. Carbon fixation via photosynthesis, and the subsequent transfer of $\mathrm{C}$ to the soil via leaf litter and root turnover, contributes to the accumulation of $\mathrm{C}$ in the soil (Leifeld and Kögel-Knabner, 2005). The higher SOC stocks in the surface layer are consistent with An (2010) and $\mathrm{Fu}$ (2010) who reported similar results. We consider the higher SOC stocks in the surface layer to be related to the higher $\mathrm{C}$ input of surface litter, roots, root exudates, and root debris. In the deeper layer, SOC stocks depend on input by roots (Rasse et al., 2005), on the microbial activity, and also on the transfer of C by the soil fauna (Fierer et al., 2003).

Our study shows that SOC stocks were the same in artificial pasture, shrubland AS and cropland. For Armeniaca sibirica shrubland, this is not consistent with the results of Yue et al. (2007) and Han et al. (2008), who showed an increase in the soil carbon stocks. Concerning artificial pasture, our findings are not in agreement with the study of Fang et al. (2012), who reported that SOC stocks were slightly lower for artificial pasture than for cropland, nor are they in agreement with the results of Wu et al. (2010), who showed that in 
Version définitive du manuscrit publié dans / Final version of the manuscript published in : Plant and Soil, 2015, 397(1), 31-42 http://dx.doi.org/10.1007/s11104-015-2486-5

artificial pasture SOC significantly increased in the topsoil $(0-10 \mathrm{~cm})$. In our study area, artificial pasture and shrubland AS did not contribute to SOC increase. This might result from the management of these two vegetation types: the artificial pasture is mowed several times a year to feed cattle, reducing the return of organic carbon to the soil, while shrublands AS in our study area are usually managed with no application of chemical or organic fertilizer. Shrubland AS allows for the harvest of wild apricot (Armeniaca sibirica Lam), increasing the income of farmers. Therefore, these two land uses cannot easily be converted to another land use that could efficiently store SOC. As an alternative, one means of increasing the SOC sequestration of these land uses could be the use of fertilizer, but this raises the issue of the fertilizer supply, additional cost and carbon footprint of the fertilizer.

Soil aggregate carbon stocks for cropland, shrubland $C K$, and natural grassland

Compared with cropland, the establishment of $C$. korshinskii shrubland caused a significant increase in large macroaggregate $(2-5 \mathrm{~mm}$ and $5-8 \mathrm{~mm}$ size) carbon stocks, and reduced the carbon stocks in small macroaggregates $(0.25-1 \mathrm{~mm}$ and $1-2 \mathrm{~mm})$ and microaggregates $(<0.25 \mathrm{~mm})$. This is not consistent with the results of Haile et al. (2008) and Wei et al. (2012), who showed that afforestation with pine (Pinus tabulaeformis Carr) enhanced carbon stocks in small macroaggregates $(0.25-2 \mathrm{~mm})$. The difference of these results could be because of the different species used in afforestation. Changes in aggregate-associated carbon stocks can be related both to changes in the amount of aggregates and in the concentration of aggregate carbon. In fact, the increase in 5-8 $\mathrm{mm}$ sized aggregate carbon stocks after shrubland CK restoration was due to the increase in both the amount and carbon concentration of the 5-8 mm size fraction. For the 2-5 $\mathrm{mm}$ size fractions, the increase in carbon stocks was due to the higher amount in the $2-5 \mathrm{~mm}$ size fraction. Overall, for $C$. korshinski shrublands, the increases in large macroaggregates were the major contributor to SOC sequestration. The increase in large macroaggregates $(2-5$ and $5-8 \mathrm{~mm}$ ) by shrubland CK restoration has been reported before: An et al. (2010) showed that these afforestation types enhanced macroaggregates. The increase in large macroaggregates by $\mathrm{CK}$ afforestation could come from a physical protection of the original and recently added carbon from microbial attack, mineralization (Beare et al. 1994; Kristiansen et al. 2006; Razafimbelo et al. 2008; Wu et al. 2012) and root activities (Rasse et al., 2005).

The capability of natural grasslands to sequester carbon has been well documented (e.g., Leahy et al. 2004; Ciais et al. 2010). However, the accumulation of carbon in soil aggregates has received less attention. Compared with cropland, we found larger carbon stocks in 1-2, 2-5, and 5-8 $\mathrm{mm}$ size fractions for natural grassland. These larger carbon stocks in $>1 \mathrm{~mm}$ sized aggregates were due to higher concentrations for all three fractions, but also to higher amounts of aggregates for the 2-5 and 5-8 mm fractions. Qiu et al. (2012) reported that the decreases in macroaggregate-associated carbon stocks accounted for more than half of SOC losses after the conversion of natural grassland to cropland. Our results indicate that the $>1 \mathrm{~mm}$ size fraction was the major contributor to the SOC accumulation in natural grassland.

Consequences of revegetation on the carbon stocks of chemically-separated fractions

Humic substances are made up of a number of compounds with a wide range of structures. They are biochemically complex and resistant to microbial degradation (Stevenson, 1994). We found that, compared with cropland, the establishment of CK shrubland induced increases in both HS-C and FA-C stocks, and induced a decrease in HA-C stocks. Natural grassland had the largest carbon stocks in HS-C, mostly due to the higher FAC stocks. This is consistent with results from Lima et al. (2006), who reported that HS-C in the 0-20 cm soil layer increased following afforestation with Eucalyptus urophylla S. Shen et al. (2014) reported that both HA-C and FA-C increased with vegetation succession (Imperata cylindrica) over 40 years. Abakumov et al. (2013) showed that HS-C and FA-C increased with grassland restoration. Higher HS-C in CK shrubland and natural grassland were due to more soil organic matter at these sites. The main factors affecting soil humification are the 
Version définitive du manuscrit publié dans / Final version of the manuscript published in :

Plant and Soil, 2015, 397(1), 31-42 http://dx.doi.org/10.1007/s11104-015-2486-5

amount of organic matter, which is the substrate for humification, and the duration of active plant-residue transformation in soil (Cerli et al. 2006, 2008). All of those results indicate that CK shrubland and natural grassland did not only result in more SOC sequestration but also in an improvement in SOC stability. Indeed, the increase in SOC sequestration could be caused by the higher SOC stability, at least partially. Additionally, we also found an increase in FA-C and relative stability in HA-C with vegetation restoration. This can be partly explained by the polyphenol theory (Stevenson, 1982): the formation of FA occurs prior to that of HA. FA has a lower molecular weight and greater mobility than HA (Zhuo et al., 1994). These results also indicate that micromolecule organic carbon was formed first following revegetation.

\section{Conclusions}

SOC stocks were small in artificial pasture, shrubland AS and cropland. They were much greater in natural grassland and $C$. korshinskii shrublands, showing the capability of these vegetation types to sequester carbon in soil. The increases in the $>2 \mathrm{~mm}$ size aggregate fraction following the establishment of $C$. korshinskii shrubland were responsible for the increase in carbon stocks, whereas the increases in the $>1 \mathrm{~mm}$ size fraction were the major contributor to SOC accumulation in natural grassland. Additionally, the higher HS-C stocks reflected the higher SOC stability in natural grassland and C. korshinskii shrublands. Therefore, to improve the contribution of vegetation to SOC sequestration, C. korshinskii shrublands should be promoted and natural grassland should be protected.

\section{Acknowledgments}

This research was supported by the National Natural Sciences Foundation of China (41171226), Program for New Century Excellent Talents in University (NCET-12-0479) and the Foundation for Youth Teachers by Northwest A\&F University (QN2011049).

\section{References}

Abakumov E V, Cajthaml T, Brus J, Frouz J (2013) Humus accumulation, humification and humic acid composition in soils of two post-mining chronosequences after coal mining. J Soils Sed 13: 491-500.

An SS, Mentler A, Mayer H, Blum WEH (2010) Soil aggregation, aggregate stability, organic carbon and nitrogen in different soil aggregate fractions under forest and shrub vegetation on the Loess Plateau, China. Catena 813: 226-233.

Ashagrie Y, Zech W, Guggenberger G (2005) Transformation of a Podocarpus falcatus dominated natural forest into a monoculture Eucalyptus globulus plantation at Munesa, Ethiopia: soil organic C, N and S dynamics in primary particle and aggregate-size fractions. Agric Ecosyst Environ 106: 89-98.

Ashagrie Y, Zech W, Guggenberger G, Mamo T (2007) Soil aggregation, and total and particulate organic matter following conversion of native forests to continuous cultivation in Ethiopia. Soil Till Res 941: 101-108.

Bambrick AD, Whalen JK, Bradley Rl, Cogliastro A, Gordon AM, Olovier A, Thevathasan NV (2010) Spatial heterogeneity of soil organic carbon in tree-based intercropping systems in Quebec and Qntario, Cadana. Agroforest Syst 79: 343-353.

Bao SD (2005) Soil Agricultural Chemistry Analysis. Beijing: China Agriculture Press.

Beare MH, Cabrera ML, Hendrix PF, Coleman DC (1994) Aggregate protected and unprotected organic matter pools inconventional and no-tillage soils. Soil Sci Soc Am J 58: 787-795.

Carter MR (1996) Analysis of soil organic matter in agroecosystems. In: Carter MR, Stewart BA (Eds.), Structure and Organic Matter Storage in Agricultural Soils. CRC Press, City, pp. 3-11.

Cerli C, Celi L, Johansson M-B, Kogel-Knabner I, Rosenqvist L, Zanini E (2006) Soil organic matter changes in a spruce chronosequence I. Carbon and lignin dynamics. Soil Sci 171: 837-849. 
Version définitive du manuscrit publié dans / Final version of the manuscript published in :

Plant and Soil, 2015, 397(1), 31-42 http://dx.doi.org/10.1007/s11104-015-2486-5

Cerli C, Celi L, Kaiser K, Guggenberger G, Johansson M-B, Cignetti A, Zanini E (2008) Changes in humic substances along an age sequence of Norway spruce stands planted on former agricultural land. Org Geochem 39: 1269-1280.

Chang R, Fu B, Liu G, Liu S (2011) Soil carbon sequestration potential for "Grain for Green" project in Loess Plateau, China. Environ Manage 486: 1158-1172.

Ciais P, Soussana JF, Vuichard N, Luyssaert S, Don A, Janssens IA, Piao SL, Dechow R, Lathlére J, Maignan F, Wattenbach M, Smith P, Ammann C, Freibauer A, Schulze ED (2010) The greenhouse gas balance of European grasslands. Biogeosciences 7: 5997-6050.

Ellert BH, Bettany JR (1995) Calculation of organic matter and nutrients stored in soils under contrasting management regimes. Can J Soil Sci 75: 529-538.

Fang X, Xue Z, Li B, An S (2012) Soil organic carbon distribution in relation to land use and its storage in a small watershed of the Loess Plateau, China. Catena 881: 6-13.

Feng X, Fu B, Lu N, Zeng Y, Wu B (2013) How ecological restoration alters ecosystem services: an analysis of carbon sequestration in China's Loess Plateau. Sci Rep 3: 2846.

Fierer N, Schimel JP, Holden A (2003) Variations in microbial community composition through two soil depth profiles. Soil Biol Biochem 35: 167-176.

Fu XL, Shao MA, Wei XR, Horton R (2010) Soil organic carbon and total nitrogen as affected by vegetation types in Northern Loess Plateau of China. Geoderma 155: 31-35.

Grigal DF (2000) Effects of extensive forest management on soil productivity. Forest Ecol Manag 138: 167-185.

Han G, Hao X, Zhao M, Wang M, Ellert BH, Willms W, Wang M (2008) Effect of grazing intensity on carbon and nitrogen in soil and vegetation in a meadow steppe in Inner Mongolia. Agr Ecosyst Environ 1251-4: 2132.

Haile SG, Nair PKR, Nair VD (2008) Carbon storage of different soil size fractions in Florida silvopastoral systems. J Environ Qual 37: 1789-1797.

Jia GM, Liu BR, Wang G, Zhang B (2010) The microbial biomass and activity in soil with shrub (Caragana korshinskii K.) plantation in the semi-arid loess plateau in China. Eur J Soil Biol 461: 6-10.

Jobbágy EG, Jackson RB (2000) The vertical distribution of soil organic carbon and its relation to climate and vegetation. Ecol Appl 10: 423-436.

Kristiansen SM, SchjØnning P, Thomsen IK, Olesen JE, Kristensen K, Christensen BT (2006) Similarity of differently sized macroaggregates in arable soils of different texture. Geoderma 137: 147-154.

Kravchenko AN, Robertson GP (2011) Whole-profile soil carbon stocks: the danger of assuming too much from analyses of too little. Soil Sci. Soc. Am. J. 75(1): 235-240.

Lal R (2004) Soil carbon sequestration to mitigate climate change. Geoderma 123: 1-22.

Leifeld J, Kögel-Knabner I (2005) Soil organic matter fractions as early indicators for carbon stock changes under different land-use? Geoderma 124: 143-155.

Leahy P, Kiely G, Scanlon TM (2004) Managed grasslands: a greenhouse gas sink or source? Geophys Res Lett 31: 205-207.

Laganière J, Angers DA, Paré D (2010) Carbon accumulation in agricultural soils after afforestation: a metaanalysis. Global Change Biol 16: 439-453.

Leng LY, Ahmed OH, Majid NM, Jalloh MB (2009) Organic matter, carbon and humic acids in rehabilitated and secondary forest soils. Am J Appl Sci 6, 711-715.

Lenka NK, Choudhury PR, Sudhishri S, Dass A, Patnaik US (2012) Soil aggregation, carbon build up and root zone soil moisture in degraded sloping lands under selected agroforestry based rehabilitation systems in eastern India. Agr Ecosyst Environ 150: 54-62. 
Version définitive du manuscrit publié dans / Final version of the manuscript published in :

Plant and Soil, 2015, 397(1), 31-42 http://dx.doi.org/10.1007/s11104-015-2486-5

Lima AMN, Silva IR, Neves JCL, Novais RF, Barros NF, Mendonça ES, Smyth TJ, Moreira MS,Leite FP (2006) Soil organic carbon dynamics following afforestation of degraded pastures with eucalyptus in southeastern Brazil. Forest Ecol Manag 2351-3: 219-231.

Li GL, Pang XM (2010) Effect of land-use conversion on C and N distribution in aggregate fractions of soils in the southern Loess Plateau, China. Land Use Policy 27: 706-712.

Mensan F, Schoenau JJ, Malhi SS (2003) Soil carbon changes in cultivated and excavated land converted to grasses in east-central Saskatchewan. Biogeochemistry 63: 85-92.

Nieto OM, Castro J, Fernández-Ondoño E (2012) Conventional tillage versus cover crops in relation to carbon fixation in Mediterranean olive cultivation. Plant Soil 365: 321-335

Nyamadzawo G, Nyamangara J, Nyamugafata P, Muzulu A. (2009) Soil microbial biomass and mineralization of aggregate protected carbon in fallow-maize systems under conventional and notillage in Central Zimbabwe. Soil Till Res 102: 151-157.

Prentice AJ, Webb EA (2010) A comparison of extraction techniques on the stable carbon-isotope composition of soil humic substances. Geoderma 155: 1-9.

Qiu L, Wei X, Zhang X, Cheng J, Gale W, Guo C, Long T (2012) Soil organic carbon losses due to land use change in a semiarid grassland. Plant Soil 355: 299-309.

Rasse DP, Rumpel C, Dignac MF (2005) Is soil carbon mostly root carbon? Mechanisms for a specific stabilization. Plant Soil 269: 341-356.

Razafimbelo TM, Albrecht A, Oliver R, Chevallier T, Chapuis-Lardy L, Feller C (2008) Aggregate associated-C and physical protection in a tropical clayey soil under Malagasy conventional and no tillage systems. Soil Till Res 98: 140-149.

Shen ZJ, Wang YP, Sun QY, Wang W (2014) Effect of Vegetation Succession on Organic Carbon, Carbon of Humus Acids and Dissolved Organic Carbon in Soils of Copper Mine Tailings Sites. Pedosphere 242: 271279.

Steffens M, Kölbl A, Kögel-Knabner I (2009) Alteration of soil organic matter pools and aggregation in semiarid steppe topsoils as driven by organic matter input. Eur J Soil Sci 602: 198-212.

Schimel DS, Hibbard KA, Bousquet P, Ciais P, Peylin P, Braswell BH, Apps MJ, Baker D, Bondeau AJC, Churkina G, Cramer W, Denning AS, Field CB, Friedlingstein P, Goodale C, Heimann M, Houghton1 JMM, Moore B, Murdiyarso D, Noble I, Pacala S W, Prentice IC, Raupach M.R, Rayner PJ, Scholes RJ, Wirth C (2001) Recent patterns and mechanisms of carbon exchange by terrestrial ecosystems. Nature 414: 8.

Six J, Elliott ET, Paustian K (2000) Soil macroaggregate turnover and microaggregate formation a mechanism for $\mathrm{C}$ sequestration under no-tillage agriculture. Soil Biol Biochem 32: 2099-2103.

Six J, Bossuyt H, Degryze S, Denef K (2004) A history of research on the link between (micro)aggregates, soil biota, and soil organic matter dynamics. Soil Till Res 791: 7-31.

Six J, Conant RT, Paul EA, Paustian K (2002) Stabilization mechanisms of soil organic matter: Implications for C-saturation of soils. Plant Soil 241: 155-176.

Skjemstad JO, Krull ES, Swift RS, Szarvas S (2008) Mecha-nisms of protection of soil organic matter under pasture following clearing of rainforest on an Oxisol. Geoderma 143: 231-242.

Stevenson FJ. 1994. Humus chemistry: genesis, composition, reactions. 2nd ed. New York, USA: Wiley.

Stevenson FJ. 1982. Humus chemistry. New York: John Wiley \& Sons.

Thomas L (1997) Retrospective Power Analysis. Conserv. Biol 11(1): 276-280.

Walkley A, Black IA (1934) An examination of the Degtjareff method for determining soil organic matter and a proposed modification of the chromic acid titration method. Soil Sci 37: 29-38. 
Version définitive du manuscrit publié dans / Final version of the manuscript published in :

Plant and Soil, 2015, 397(1), 31-42 http://dx.doi.org/10.1007/s11104-015-2486-5

Wei X, Li X, Jia X, Shao M (2012) Accumulation of soil organic carbon in aggregates after afforestation on abandoned farmland. Biol Fert Soils 496: 637-646.

Wu GL, Liu ZH, Zhang L, Hu TM, Chen JM (2010) Effects of artificial pasture establishment on soil nutrients and carbon properties in a black-soil-type degraded grassland. Plant Soil 333: 469-479.

Wu H, Wiesmeier M, Yu Q, Steffens M, Han X, Kögel-Knabner I (2012) Labile organic C and N mineralization of soil aggregate size classes in semiarid grasslands as affected by grazing management. Biol Fertil Soils 48: $305-313$.

Yue QL, Liu J, Tao WF, Liu WJ (2007) Soil fertilizer change of different artificial forest on the Loess Plateau Gully. Agricultural Research in the Arid Areas 253: 6.

Yan CS (1988) The Soil Fertility Research Methods. Beijing: China Agricultural Press, City, pp 124-128.

Zhuo SN, Wen QX (1994) The alcohol fractional precipitation classification of humic acid. Acta Pedol Sinica 31: 124-128.

Zhu XM (1982) Soil and Agriculture in Loess Plateau (in Chinese). Agricultural Press, Beijing. 
Version définitive du manuscrit publié dans / Final version of the manuscript published in :

Plant and Soil, 2015, 397(1), 31-42 http://dx.doi.org/10.1007/s11104-015-2486-5

Table 1 Vegetation characteristics of soil sampling sites in the Shanghuang study area. Above-ground biomass and plant surface coverage are mean values with standard errors $(P<0.05)$.

\begin{tabular}{|c|c|c|c|c|}
\hline Vegetation type & Dominant species & $\begin{array}{l}\text { Understory/accessory } \\
\text { species }\end{array}$ & $\begin{array}{l}\text { Plant } \\
\text { surface } \\
\text { coverage } \\
(\%)\end{array}$ & $\begin{array}{l}\text { Above- } \\
\text { ground } \\
\text { biomass } \\
\left(\mathrm{Mg} \mathrm{ha}^{-1}\right)\end{array}$ \\
\hline Shrubland CK16 & $\begin{array}{l}\text { Caragana Korshinskii } \\
\text { Kom. }\end{array}$ & $\begin{array}{l}\text { Artemisia sacrorum Ledeb. } \\
\text { Stipabungeana Trin. }\end{array}$ & $40 \pm 5$ & $14 \pm 1$ \\
\hline Shrubland CK26 & $\begin{array}{l}\text { Caragana Korshinskii } \\
\text { Kom. }\end{array}$ & $\begin{array}{l}\text { Artemisia sacrorum Ledeb. } \\
\text { Stipabungeana Trin. }\end{array}$ & $64 \pm 3$ & $27 \pm 2$ \\
\hline Shrubland AS & Armeniaca sibirica Lam. & $\begin{array}{l}\text { Artemisia sacrorum Ledeb. } \\
\text { Leymus secalinus Tzvel }\end{array}$ & $42 \pm 8$ & not measured \\
\hline Natural grassland & Stipa bungeana Trin. & $\begin{array}{l}\text { Artemisia sacrorum } \\
\text { Ledeb. } \\
\text { Leymus secalinus Tzvel. } \\
\text { Agropyron cristatum } \\
\text { Gaertn. } \\
\text { Thymus mongolicus }\end{array}$ & $75 \pm 6$ & $14 \pm 1$ \\
\hline Artificial pasture & Medicago sativa Linn & & $88 \pm 3$ & not measured \\
\hline Cropland & Triticum aestivum Linn. & not measured & $\begin{array}{l}\text { not } \\
\text { measured }\end{array}$ & not measured \\
\hline
\end{tabular}

Note: Shrubland CK16= 16-year-old Caragana korshinskii Kom.; Shrubland CK26= 26-year-old Caragana korshinskii Kom.; Shrubland AS=Armeniaca sibirica Lam. 
Version définitive du manuscrit publié dans / Final version of the manuscript published in :

Plant and Soil, 2015, 397(1), 31-42 http://dx.doi.org/10.1007/s11104-015-2486-5

Table 2 General situation of the sites used for aggregate and carbon characterization in the study area.

\begin{tabular}{lllll}
\hline Vegetation type & Elevation $(\mathrm{m})$ & Slope $\left({ }^{\circ}\right)$ & Topography & Soil type
\end{tabular}

\begin{tabular}{lllll}
\hline Shrubland CK16 & 1670 & 18 & Middle slope & Entisols \\
Shrubland CK26 & 1670 & 25 & Middle slope & Entisols \\
Natural grassland & 1675 & 16 & Upper slope & Entisols \\
Cropland & 1620 & 5 & Middle slope & Entisols \\
\hline
\end{tabular}

Note: Shrubland CK16= 16-year-old Caragana korshinskii Kom.; Shrubland CK26= 26-year-old Caragana korshinskii Kom. 
Version définitive du manuscrit publié dans / Final version of the manuscript published in :

Plant and Soil, 2015, 397(1), 31-42 http://dx.doi.org/10.1007/s11104-015-2486-5

Table 3 SOC stocks for the vegetation types (mean and standard error)

\begin{tabular}{lrrrr}
\hline Vegetation types & $\mathrm{n}$ & \multicolumn{3}{c}{ Soil organic carbon stocks $\left(\mathrm{Mg} \mathrm{ha}^{-1}\right)$} \\
& & & & \\
& 17 & $23 \pm 10 \mathrm{abA}$ & $15 \pm 6 \mathrm{abB}$ & $38 \pm 16 \mathrm{ab}$ \\
Shrubland CK16 & 17 & $30 \pm 9 \mathrm{aA}$ & $22 \pm 4 \mathrm{aB}$ & $51 \pm 10 \mathrm{a}$ \\
Shrubland CK26 & 12 & $15 \pm 6 \mathrm{bA}$ & $9 \pm 4 \mathrm{bB}$ & $24 \pm 10 \mathrm{~b}$ \\
Shrubland AS & 15 & $32 \pm 12 \mathrm{aA}$ & $23 \pm 8 \mathrm{aB}$ & $55 \pm 18 \mathrm{a}$ \\
Natural grassland & 19 & $14 \pm 5 \mathrm{bA}$ & $11 \pm 4 \mathrm{bA}$ & $25 \pm 8 \mathrm{~b}$ \\
Artificial pasture & 19 & $14 \pm 8 \mathrm{bA}$ & $12 \pm 6 \mathrm{bA}$ & $26 \pm 14 \mathrm{~b}$ \\
Cropland & &
\end{tabular}

Note: Different lower-case letters indicate significant differences at $P<0.05$ among different vegetation types for a given soil depth. Different capital letters indicate significant differences at $P<0.05$ among soil depths for a given vegetation type. Shrubland CK16=16-year-old Caragana korshinskii Kom.; Shrubland CK26= 26-yearold Caragana korshinskii Kom.; Shrubland AS=Armeniaca sibirica Lam. SOC=soil organic carbon. $\mathrm{n}=$ number of sites. 
Version définitive du manuscrit publié dans / Final version of the manuscript published in :

Plant and Soil, 2015, 397(1), 31-42 http://dx.doi.org/10.1007/s11104-015-2486-5

Table 4 Soil organic carbon stocks $\left(\mathrm{Mg} \mathrm{ha}^{-1}\right)$ in HS, HA, and FA for shrubland CK16, shrubland CK26, natural grassland and cropland (mean and standard error; $\mathrm{n}=18$ ).

\begin{tabular}{|c|c|c|c|c|c|c|}
\hline \multirow[t]{2}{*}{ Vegetation types } & \multicolumn{2}{|c|}{ HS-C stocks } & \multicolumn{2}{|c|}{ FA-C stocks } & \multicolumn{2}{|c|}{ HA-C stocks } \\
\hline & $0-20 \mathrm{~cm}$ & $20-40 \mathrm{~cm}$ & $0-20 \mathrm{~cm}$ & $20-40 \mathrm{~cm}$ & $0-20 \mathrm{~cm}$ & $20-40 \mathrm{~cm}$ \\
\hline Shrubland CK16 & $3.9 \pm 0.1 \mathrm{aA}$ & $1.8 \pm 0.3 \mathrm{bB}$ & $3.0 \pm 0.1 \mathrm{aA}$ & $1.6 \pm 0.3 \mathrm{abB}$ & $0.9 \pm 0.1 \mathrm{aA}$ & $0.3 \pm 0.1 \mathrm{aB}$ \\
\hline Shrubland CK26 & $4.2 \pm 0.7 \mathrm{aA}$ & $3.2 \pm 0.2 \mathrm{aA}$ & $2.9 \pm 0.8 \mathrm{aA}$ & $\begin{array}{l}2.3 \pm 0.1 \mathrm{ab} \\
\mathrm{A}\end{array}$ & $1.2 \pm 0.1 \mathrm{aA}$ & $0.8 \pm 0.3 \mathrm{aA}$ \\
\hline Natural grassland & $4.9 \pm 0.5 \mathrm{aA}$ & $3.5 \pm 0.4 \mathrm{aA}$ & $3.7 \pm 0.4 \mathrm{aA}$ & $2.8 \pm 0.3 \mathrm{aA}$ & $1.2 \pm 0.2 \mathrm{aA}$ & $0.4 \pm 0.2 \mathrm{aB}$ \\
\hline Cropland & $2.5 \pm 0.2 \mathrm{bA}$ & $1.8 \pm 0.3 \mathrm{bA}$ & $1.5 \pm 0.3 \mathrm{bA}$ & $1.3 \pm 0.3 \mathrm{bA}$ & $1.0 \pm 0.1 \mathrm{aA}$ & $0.5 \pm 0.1 \mathrm{aB}$ \\
\hline
\end{tabular}

Note: Different lower-case letters indicate significant differences at $P<0.05$ among different vegetation types. Different capital letters indicate significant differences at $P<0.05$ among soil depths for a given vegetation type. Shrubland CK16=16-year-old Caragana korshinskii Kom.; Shrubland CK26= 26-year-old Caragana korshinskii Kom. $\mathrm{HS}=$ humus. $\mathrm{HA}=$ humic acid. FA = fulvic acid. 
Version définitive du manuscrit publié dans / Final version of the manuscript published in :

Plant and Soil, 2015, 397(1), 31-42 $\quad$ http://dx.doi.org/10.1007/s11104-015-2486-5

Fig. 1. The location of the study area and its land use. (a) Location of the Ningxia Province and the Loess Plateau in China; (b) Location of the Shanghuang study area in the Ningxia Autonomous Region, (c) Contour lines and soil sampling sites in the study area, (d) Vegetation types of the study area.

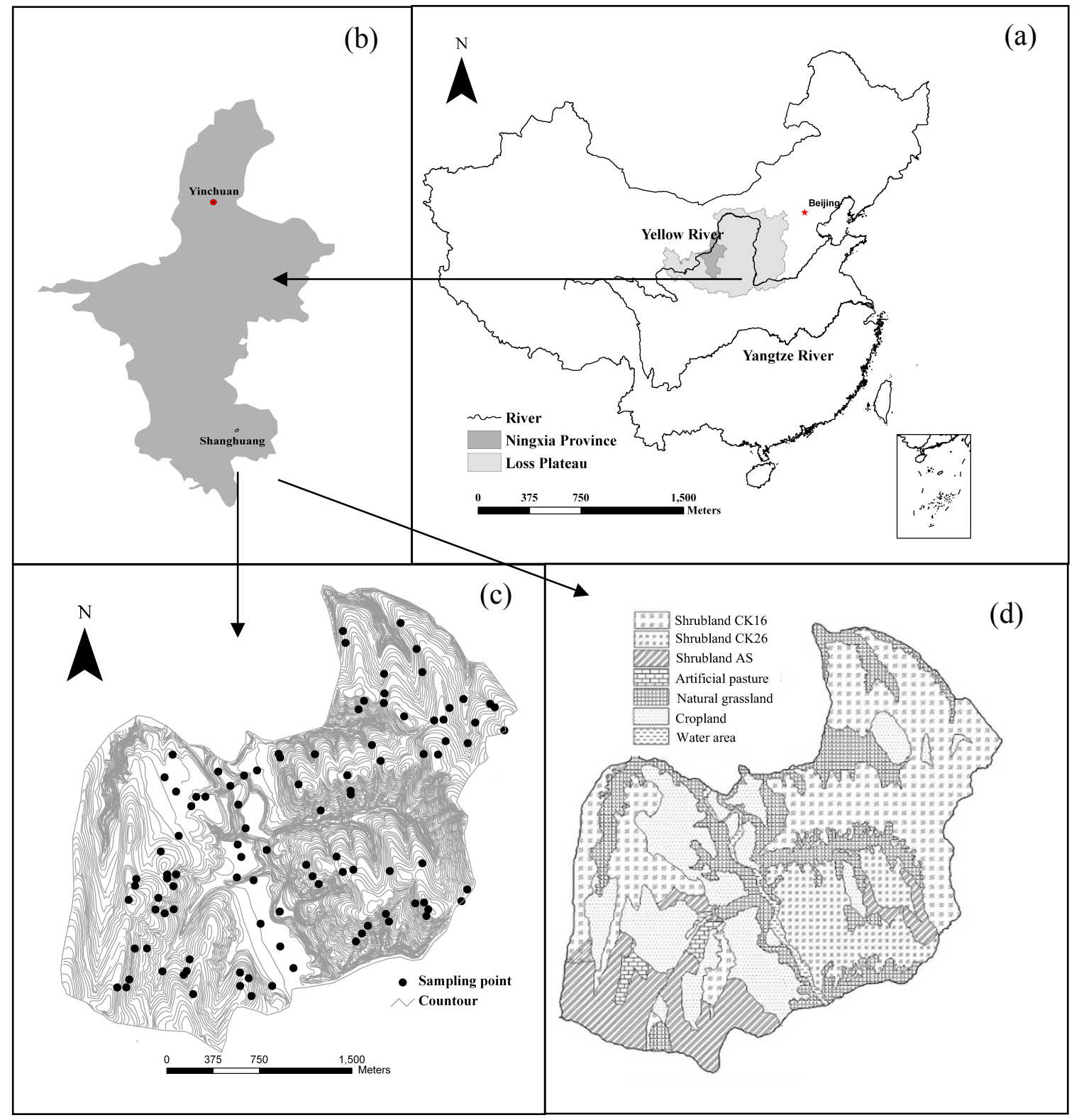

Note: Shrubland CK16= 16-year-old Caragana korshinskii Kom.; Shrubland CK26= 26-year-old Caragana korshinskii Kom.; Shrubland AS=Armeniaca sibirica Lam. 
Version définitive du manuscrit publié dans / Final version of the manuscript published in :

Plant and Soil, 2015, 397(1), 31-42 http://dx.doi.org/10.1007/s11104-015-2486-5

Fig. 2. Probability (power) of detecting a $25 \%$ uncertainty in soil organic carbon stocks with a 0.05 level of significance for vegetation types at 0-20 and $20-40 \mathrm{~cm}$ soil layers.

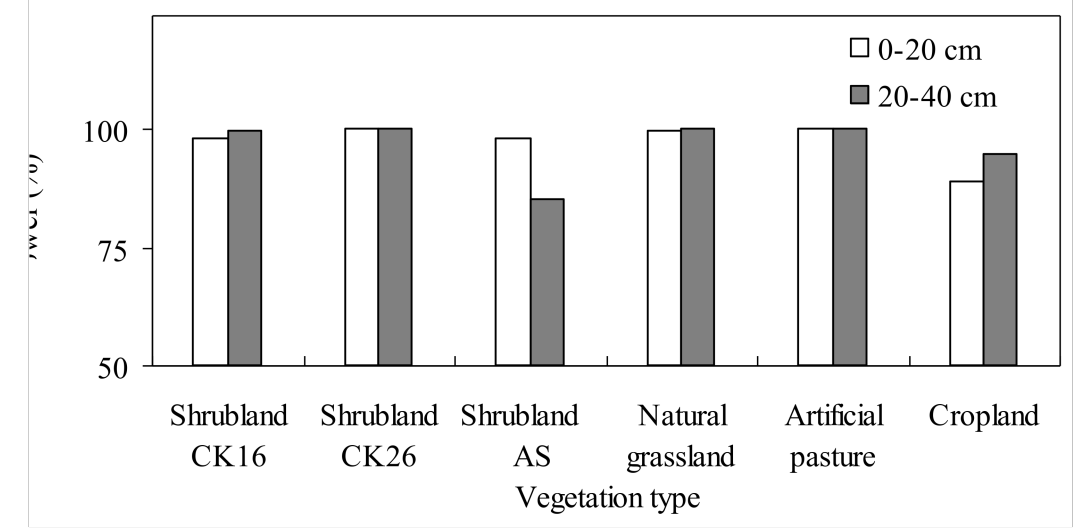


Version définitive du manuscrit publié dans / Final version of the manuscript published in :

Plant and Soil, 2015, 397(1), 31-42 $\quad$ http://dx.doi.org/10.1007/s11104-015-2486-5

Fig. 3. Vegetation types and (a) aggregate amount, (b) soil organic carbon concentration in aggregate fractions, (c) soil organic carbon stocks in aggregate fractions.
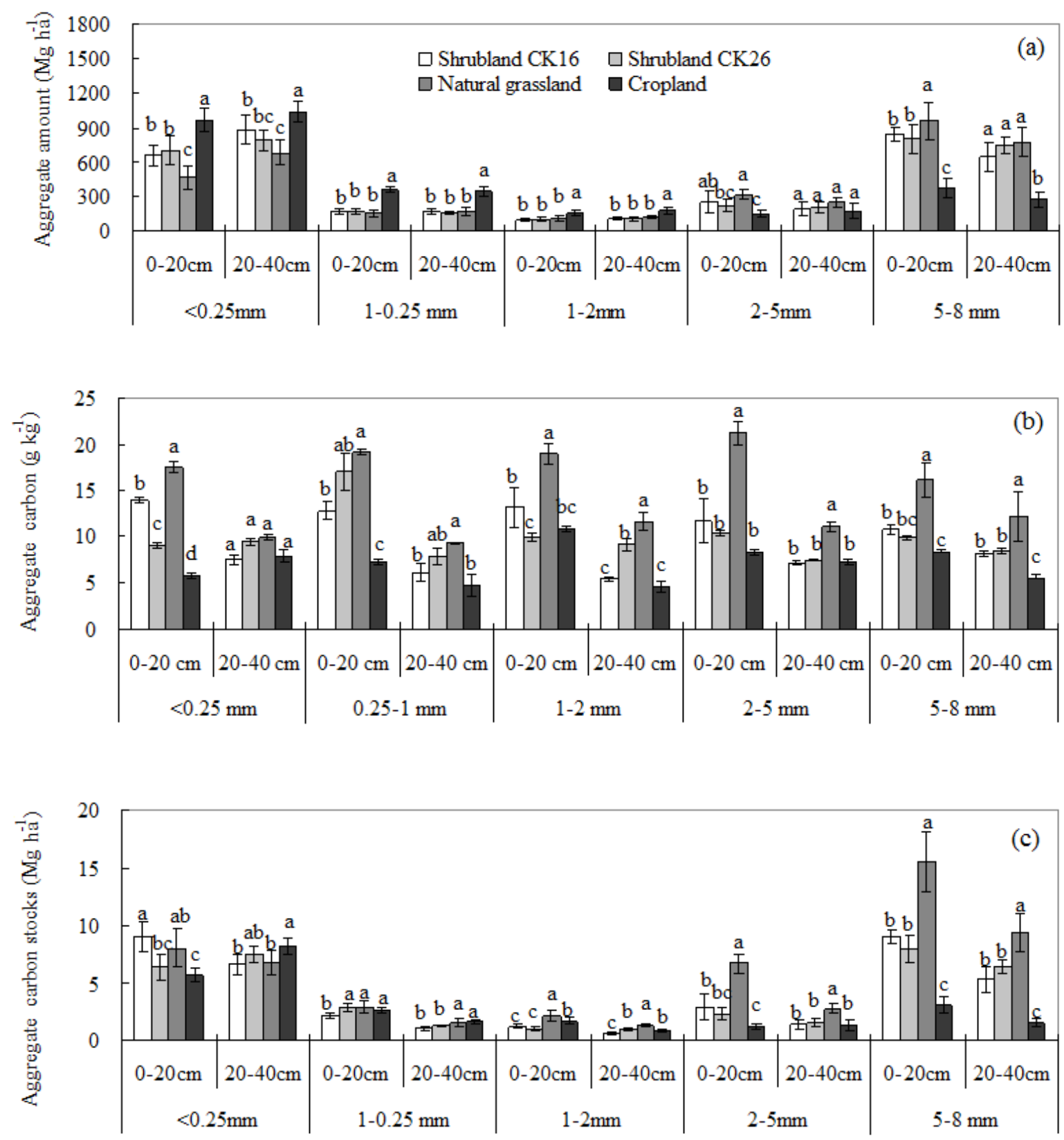

Note: Bars are standard errors; different lower-case letters indicate significant differences at $P<0.05$ among vegetation types within each aggregate size $(\mathrm{n}=18)$. Shrubland CK16=16-year-old Caragana korshinskii Kom.; Shrubland CK26=26-year-old Caragana korshinskii Kom. 